\title{
Pengaruh Self-Regulated Learning terhadap Kemampuan Berpikir Reflektif Matematis Siswa
}

\author{
Maura Noverienda Armelia ${ }^{1}$, Ismail ${ }^{2}$ \\ ${ }^{1,2}$ Program Studi Pendidikan Matematika, Fakultas Matematika dan Ilmu Pengetahuan Alam, Universitas Negeri Surabaya \\ Jl. Ketintang, Ketintang, Kec. gayungan, Kota SBY, Jawa Timur \\ Maura.17030174064@mhs.unesa.ac.id
}

\begin{abstract}
The ability to think reflectively is a higher order thinking ability. However, Indonesia has low category of reflective thinking ability. In developing reflective thinking, self-regulated learning strategies can be used. The purpose of this study was to analyze the effect of self-regulated learning strategies on students' mathematical reflective thinking skills which was carried out at SMP Negeri 2 Surabaya. Quasi experiment is the method used. The design used is a randomized control group posttest only. The samples used are IX-I and IX-J. To determine the sample, using cluster random sampling consisting of experimental and control classes. What was done for data collection was to do a test on reflective thinking after giving treatment that was adjusted to the strategy used. The results of this study are the influence of self-regulated learning strategies on students' mathematical reflective thinking skills. It can be seen from the hypothesis test which shows the p-value (0.05) which means that the mathematical reflective thinking ability of students whose learning uses self-regulated learning strategies is higher than the control class.
\end{abstract}

Keywords: reflective thinking ability, expository, self-regulated learning

\begin{abstract}
Abstrak
Kemampuan berpikir reflektif merupakan kemampuan berpikir tingkat tinggi. Namun, Indoneisa termasuk mempunyai kemampuan berpikir reflektif kategori rendah. Dalam meneaikan berpikir reflektif dapat menggunaka strategi pembelajaran self-regulated learning. Tujuan penelitian ini menganlisis adanya pengaruh strategi selfregulated learning terhadap kemampuan berpikir reflektif matematis siswa yang dilaksanakan di SMP Negeri 2 Surabaya. Quasi eksperimen merupakan metode yang digunakan. Design yang digunakan yaitu randomized control group posttest only. Yang digunakan sebagai sampel yaitu IX-I dan IX-J. Untuk menentukan sampel yaitu menggunakan cluster random sampling yang terdiri atas kelas eksperimen dan kontrol. Yang dilakukan untuk pengambilan data yaitu melakukan tes mengenai berpikir reflektif setelah pemberian perlakukan yang disesuaikan dengan strategi yang digunakan. Hasil dari penelitian ini adalah adanya pengaruh dari strategi self-regulated learning terhadap kemampuan berpikir reflektif matematis siswa. Dapat dilihat dari uji hipotesis yang memperlihatkan $\mathrm{p}$-value $\leq \alpha(0,05)$ yang artinya kemampuan berpikir reflektif matematis siswa yang pembelajarannya menggunakan strategi self-regulated learning lebih tinggi apabila dibandingkan kelas control yang menggunakan strategi ekspositori.
\end{abstract}

Kata kunci: kemampuan berpikir reflektif, ekpositori, self-regulated learning.

Copyright (c) 2021 Maura Noverienda Armelia, Ismail

$\triangle$ Corresponding author: Maura Noverienda Armelia

Email Address: Maura.17030174064@mhs.unesa.ac.id (Jl. Ketintang, Ketintang, Kec. gayungan, Kota SBY, Jawa Timur)

Received 12 Juni 2021, Accepted 21 Juni 2021, Published 28 Juni 2021

\section{PENDAHULUAN}

Menurut Krulik bahwa berpikir tingkat tinggi meliputi berpikir kreatif, reflektif, logis serta kritis (Hidayat \& Sumarmo, 2013). Dari keempat kemampuan yang dipaparkan menurut (Kusumaningrum \& Saefudin, 2012) berpikir reflektif matematis yang sampai saat ini dikembangkan dan didalami adalah kemampuan berpikir reflektif matematis. John dewey menyatakan bahwa berpikir reflektif merupakan proses berpikir yang dianggap terbaik. Karena dalam proses ini mempunyai proses memahami masalah, meneliti serta menggali informasi sampai tahap memecahkan maslaah (Sudarma, 2016). Menurut Taggart mengenai berpikir reflektif adalah suatu proses menyusun informasi serta menciptakan keputusan yang 
berdasarkan fakta mengenai pendidikan, dilanjutkan dengan memberi nilai keputusan tersebut (Fuady, 2006). Menurut (Dewey, 1933) mengenai berpikir reflektif adalah pemikiran mengenai sesuatu yang sudah dipertimbangkan dengan hati-hati sesuai dengan pengetahuan yang logis dan benar kemudian dilanjutkan dengan menyimpulkan pemikiran tersebut. Dari pendapat tersebut disimpulkan bahwa berpikir reflektif yaitu proses membuat informasi dengan pertimbangan yang dilakukan dengan hati-hati saat membuat keputusan yanng logis mengenai pendidikan, yang dilanjutkan dengan menilai keputusan tersebut.

Reflektif dalam matematika dapat dikatakan sebagai alat untuk mengembangkan kemampuan yang dimiliki siswa dalam menggunakan konsep matematika untuk mengatasi permasalahan dan untuk ikut memasuki kedalam pemikiran yang lebih dalam mengenai masalah tersebut menurut Prabha dalam (Nikmah, 2018) Pengembangan kemampuan berpikir reflektif menurut pandangan Pragmatism (Masamah, 2017) menutut seorang guru bisa menciptakan suasana yang membuat siswa merasa adanya suatu masalah yang harus dipecahkan, serta dapat menciptakan kerjasama dalam belajar. Tetapi, ditemukan oleh Marpaung (Masamah, 2017) bahwa selama ini di pembelajaran matematika siswa hampir tidak pernah dituntut untuk menggunakan berbagai strategi dalam hal memecahkan masalah. Ada beberapa siswa yang tidak bisa menemukan solusi pemecahan masalah dengan cepat, dan apabila solusi sudah ditemukan siswa cenderung cepat merasa puas dan menyudahi proses belajarnya. Akibat hal tersebut, kemampuan berpikir reflektif siswa lemah karena pembelajaran yang dilakukan hanya mendorong siswa untuk berpikir setara tingkat rendah.

Dikemukakan (Sabandar, 2009)bahwa berpikir reflektif matematis masih jarang diperkenalkan guru dan dikembangkan pada siswa sekolah menengah. Kondisi pembelajaran seperti itu merupakan salah satu alasan rendahnya kemampuan berpikir reflektif matematis. Dan juga hasil tes PISA tahun 2015 menjadi bukti rendahnya kemampuan berpikir reflektif matematis. Dan penelitian yang dilakukan oleh Nindiasari (Nindiasari et al., 2014) yang melibatkan beberapa siswa pada tiga level sekolah yaitu tinggi, sedang, rendah di Tanggerang. Yang menunjukkan bahwa dari ketiga sekolah tersebut siswanya belum terbiasa mengerjakan soal berpikir reflektif matematis di sekolah, dilihat dari skor yang didapat masih jauh dari skor ideal.

Menurut Dewey (Anwar, 2018) mengenai proses berpikir memiliki langkah-langkah yang akan dijalankan oleh seorang individu, diantaranya : 1. Individu merasa ada suatu masalah. 2 . Individu membatasi pemahamannya terhadap suatu masalah. 3. Individu mendapatkan hubungan antar masalah kemudian merumuskan hipotesis berdasarkan pengetahuan yang diketahui 4. Individu mengevaluasi hipotesis yang telah dirumuskan . 5. Individu mempraktikan upaya dalam memecahkan masalah yang sudah dibuat, yang dilanjutkan dengan menyimpulkan hasilnya.

Kemampuan berpikir reflektif memiliki indikat, diantaranya : a) mendefinisikan masalah atau menginterpretasi masalah. b) mengevaluasi kebenaran suatu argumen. c) menganalisis permasalah. d) menarik analogi

Agar kemampuan berpikir reflektif ini mampu berjalan dengan baik sehingga dibutuhkan kemandirian belajar siswa dalam menyelesaikan masalah-masalah yang akan di hadapi (Hidayat \& 
Pengaruh Self-Regulated Learning terhadap Kemampuan Berpikir Reflektif Matematis Siswa, Maura Noverienda Armelia,

Sumarmo, 2013). Self-Regulated Learning juga bisa disebut suatu kemandirian dalam belajar yang merupakan strategi belajar secara kognitif (Latipah, 2015). Maka dengan Self-Regulated Learning siswa mampu mengendalikan dirinya sendiri sehingga belajar. siswa menjadi lebih termotivasi untuk menggapai tujuan belajarnya. Dalam belajar siswa diberi kebabasan untuk berekspresi, sehingga dalam melakukan pembelajaran siswa tidak merasa terpaksa dan bisa menunjukkan kemampuan terbaik yang dimilikinya.

Menurut B.J. Zimmerman dan Risemberg (1997) dalam (Mukhid, 1998) Self-Regulated Learning adalah gerakan mengatur diri sendiri atau Self-Initiated yang meliputi usaha-usaha pengaturan demi mencapai tujuan, pengaturan waktu dan lingkungan. Menurut Pintrich, Self-Regulated Learning adalah kegiatan yang mengendalikan dirinya sendiri dengan memonitor, mengatur serta mengontrol diri sendiri sesuai dengan tujuan menyelesaikan masalah yang dihadapi. Berdasarkan penjelasan strategi pembelajaran dan Self-Regulated Learning tersebut bisa disimpulkan bahwa strategi Self-Regulated Learning merupakan startegi pembelajaran. yang menuntuut siswa untuk bertanggung jawab bagi dirinya sendiri dengan memonitor, mengatur dan mengontrol pengetahuannya untuk mencapai tujuan yang akan dituju.

Menururt Zimmerman dalam pembelajaran matematika dapat diimplementasikan menggunakan strategi Self-Regulated Learning yang terdapat tiga tahap yaitu dalam (Fahiroh, 2020): Forethought (pemikiran), Performance (kinerja), Self-Reflection (refleksi diri). Salah satu strategi pembelajaran yang juga dapat digunakan dalam pembelajaran matematika adalah strategi ekspositori. Strategi ini merupakan strategi yang bertolak belakang dengan Self-Regulated Learning. Karena strategi ekspositori ini merupakan pendekatan pembelajaran yang berpusat pada guru (Teacher Centered Approach). Maksud dari strategi ekspositori adalah pelaksanaan pembelajaran yang dilakukan dengan menghubungkan antara metode ceramah dengan metode tanya jawab. Menurut Roy Killen dalam (Suyadi, 2013) menyebut strategi pembelajaran ekspositori ini dengan istilah pembelajaran langsung.

Dalam (Sagala, 2010) menurut Ausubel menyatakan strategi ekspositori merupakan strategi pembelajaran yang dirasa paling efisen serta efektif di kegiatan pembelajaran. Dalam strategi ini siswa dapat saling berdiskusi dengan temannya dalam mengerjakan soal latihan yang diberikan oleh guru. Dalam strategi ini guru adalah peran penting dalam pembelajaran. Oleh karena itu, guru harus mempunyai ide yang inovatif agar pembelajaran dalam berjalan dengan baik. Strategi ekspositori ini masih banyak digunakan disekolah-sekolah, walaupun saat ini menggunakan kurikulum 2013. Karena ada pembelajaran yang dirasa perlu menggunakan strategi ekspositori yang dengan cara metode ceramah. Dan dianggap peserta didik mempu mengimplementasikan dalam pembelajaran.

Menurut Wina (Hidayati et al., 2016) strategi ekspositori mempunyai tahapan pelaksanaan dalam pembelajaran yaitu fase persiapan, fase penyajian, fase korelasi, fase menyimpulkan, dan fase mengaplikasikan. Fase persiapan yaitu fase dimana guru mengarahkan siswa untuk menyaipkan diri sebelum kegiatan belajar mengajar dimulai. Kemudian fase penyajian yaitu Guru menyampaikan materi dengan memberikan contoh secara kontekstual agar siswa dapat menerima pembelajaran lebih mudah. Selanjutnya fase korelasi adalah langkah yang digunakan untuk memberikan makna mengenai suatu pelajaran. Selanjutnya fase menyimpulkan yaitu tahap untuk memahami inti dari materi pembelajaran yang 
telah di pelajari dengan cara menyimpulkannya. Yang terakhir yaitu fase mengaplikasikan, dalam fase ini siswa menunjukkan kemampuannya seteah menyimak penjelasan dari guru dengan mengerjakan tugastugas yang diberikan oleh guru. Dalam fase terakhir ini adalah fase terpenting karena guru bisa mengumpulkan informasi mengenai penguasaan dan pemahaman siswa terhadap materi yang telah dipelajari.

Pada penelitian yang dilakukan oleh ika (Hidayati et al., 2016) menyatakan bahwa adanya strategi ekspositori dapat meningkatkan prestasi belajar siswa. Dan penelitian yang dilakukan oleh Ronald (Hamonangan \& Widyarto, 2019) menunjukkan bahwa ada pengaruh self-regulated learning terhadap hasil belajar matematika siswa. Dari pemamparan tersebut antara strategi self-regulated learning dan strategi ekspositori sama-sama strategi yang bertujuan baik dalam pembelajaran matematika. Hanya saja cara pembelajaraannya yang berbeda. Dimana strategi self-regulated learning pembelajarannya menuntut siswa untuk menemukan dan memecahkan masalah. Sedangkan strategi ekspositori pembelajarannya berpusat kepada guru, dimana dalam pembelajarannya guru yang berperan aktif. Kedua strategi tersebut bisa menjadi pengaruh meningkatnya kemampuan berpikir reflektif matemtatis siswa. Pada penelitian ini ingin mengetahui antara strategi self-regulated learning dengan strategi ekspositori yang paling berpengaruh terhadap kemampuan berpikir reflektif matematis siswa. oleh karena itu peneliti akan melakukan penelitian dengan judul "Pengaruh Self-Regulated Learning Dalam Kemampuan Berpikir Reflektif Matematis Siswa". Yang tujuannya untuk mengetahui pengaruh Self-Regulated Learning dalam kemampuan berpikir reflektif matematis siswa.

\section{METODE}

Metode penelitian ini yaitu kuasi eksperimen. Dengan cara membandingkan kemampuan berpikir reflektif matematis siswa kelas eksperimen dan kelas kontrol. Kelas eksperimen merupakan kelas yang memakai strategi Self-Regulated Learning sedangkan kelas kontrol adalah kelas yang memakai strategi ekspositori. Desain yang digunakan yaitu Randomized Posttest Only Control Group Design artinya tes yang hanya dilaksanakan pada saat tahap akhir. Design ini digunakan di karenakan ingin menganalisis skor tes tersebut dan ini mengetahui perbedaan dari hasil tes kemampuan berpikir reflektif antara kedua kelas yang terlibat apabila diberikan perlakukan berbeda. Analisis data yang digunakan adalah analisis Independent Samples $T$ Test. Analisis ini digunakan dengan menguji dua rata-rata sampel bebas, yaitu sampel yang keberadaanya tidak saling mempengaruhi (independen).

Penelitian ini dilakukan di SMP Negeri 2 Surabaya yang berada di Jl. Kepanjen No.1 Surabaya. Dalam penelitian ini dilakukan pada semester genap di bulan Januari tahun 2021. Banyak populasi penelitian ini adalah seluruh siswa kelas IX di SMPN 2 Surabaya di semester genap tahun ajaran 2020/2021 terdiri dari 10 kelas. Teknik sampling yang digunakan yaitu cluster random sampling. Pengambilan sampel secara cluster random sampling ini merupakan cara mengambil cara secara random yang didasari pada kelompok, tidak didasari dari anggota-anggotanya, dengan catatan anggota dari kelompok tersebut memiliki 
Pengaruh Self-Regulated Learning terhadap Kemampuan Berpikir Reflektif Matematis Siswa, Maura Noverienda Armelia, Ismail

karakteristik yang sama. Pengambilan sampel ini dilakukan secara random oleh karena itu setiap anggota populasi mempunya peluang yang sama (Sugiyono, 2012).

Sampel penelitian yakni kelas IX-I dan kelas IX-J, kelas tersebut didapat setelah melotre dari sepuluh kelas yang ada pada kelas IX di SMPN 2 Surabaya. Kelas IX-J yang berjumlah sebanyak 42 siswa dengan pembelajaran yang digunakan adalah strategi Self-Regulated Learning dan kelas IX-I dengan jumlah 41 siswa, dimana IX-I menjadi kelas kontrol yang pembelajarannya menggunakan strategi pembelajaran ekspositori. Model desain pada penelitian ini dapat dilihat pada tabel dibawah ini (Sukmadinata \& Nana, 2008) :

Tabel 1. Desain Penelitian

\begin{tabular}{|c|c|c|}
\hline Kelompok & Treatment & Post Test \\
\hline $\mathrm{E}$ & $X_{E}$ & $\mathrm{Y}$ \\
\hline $\mathrm{C}$ & $X_{C}$ & $\mathrm{Y}$ \\
\hline
\end{tabular}

Keterangan:

E: Kelompok eksperimen

C: Kelompok kontrol

$\mathrm{X}_{\mathrm{E}}$ : Perlakukan pada kelompok eksperimen menggunakan strategi Self-Regulated Learning

$\mathrm{X}_{\mathrm{C}}$ : Perlakukan pada kelompok kontrol menggunakan strategi ekspositori

Y: Tes Kemampuan bepikir reflektif matematis

Instrumen yang digunakan adalah soal essay. Soal essay ini digunakan sebagai Post Test. Post Test ini diberikan kepada kelas eksperimen dan kelas kontrol untuk menilai kemampuan yang dimiliki mengenai kemampuan berpikir reflektif matematis. Soal Post Test berjumlah enam soal digunakan mengukur kemampuan berpikir reflektif matematis yang sudah divalidasi dengan dosen pembimbing.

Sebelum diberikan Post Test melakukan pembelajaran selama dua kali pertemuan. Pada kelas kontrol dan eksperimen diberikan pembelajaran mengenai materi kesebangunan dan kekongruenan menggunakan strategi ekspositori dan strategi Self-Regulated Learning yang sudah disesuaikan dengan langkah-langkah masing-masing strategi. Adapun indikator yang akan diukur adalah sebagai berikut :

Tabel 2. Indikator soal Kemampuan berpikir Reflektif Matematis

\begin{tabular}{|c|c|c|c|c|c|c|c|c|}
\hline \multirow[b]{2}{*}{$\begin{array}{c}\text { Kompetensi } \\
\text { Dasar }\end{array}$} & \multirow[b]{2}{*}{ Indikator Soal } & \multirow[b]{2}{*}{ Kisi-kisi Soal } & \multicolumn{4}{|c|}{ Indikator KBRM } & \multirow{2}{*}{$\begin{array}{l}\text { No. } \\
\text { Butir } \\
\text { Soal }\end{array}$} & \multirow{2}{*}{$\begin{array}{c}\text { Jumlah } \\
\text { Butir } \\
\text { Soal } \\
\end{array}$} \\
\hline & & & 1 & 2 & 3 & 4 & & \\
\hline \multirow[t]{2}{*}{$\begin{array}{l}3.6 \\
\text { Menjelaskan dan } \\
\text { menentukan } \\
\text { kesebangunan } \\
\text { dan } \\
\text { kekongruenan } \\
\text { antar bangun } \\
\text { datar }\end{array}$} & \multirow[t]{2}{*}{$\begin{array}{l}\text { 1. Menentukan } \\
\text { bangun datar/ } \\
\text { dua segitiga } \\
\text { yang kongruen }\end{array}$} & $\begin{array}{l}\text { Menentukan dua } \\
\text { segitiga terebut } \\
\text { konguren atau tidak } \\
\text { dengan } \\
\text { mencantumkan bukti } \\
\text { apabila dua segitu } \\
\text { tersebut kongruen. }\end{array}$ & $\checkmark$ & & & & 1 & \multirow[t]{2}{*}{2} \\
\hline & & $\begin{array}{l}\text { Mencari dua segitiga } \\
\text { yang kongruen dari }\end{array}$ & $\checkmark$ & & & & 2 & \\
\hline
\end{tabular}




\begin{tabular}{|c|c|c|c|c|c|c|c|c|}
\hline \multirow[b]{2}{*}{$\begin{array}{l}\text { Kompetensi } \\
\text { Dasar }\end{array}$} & \multirow[b]{2}{*}{ Indikator Soal } & \multirow[b]{2}{*}{ Kisi-kisi Soal } & \multicolumn{4}{|c|}{ Indikator KBRM } & \multirow{2}{*}{$\begin{array}{l}\text { No. } \\
\text { Butir } \\
\text { Soal }\end{array}$} & \multirow{2}{*}{$\begin{array}{c}\text { Jumlah } \\
\text { Butir } \\
\text { Soal }\end{array}$} \\
\hline & & & 1 & 2 & 3 & 4 & & \\
\hline & & $\begin{array}{l}\text { suatu bangun datar } \\
\text { dan menyertakan } \\
\text { penjelasannya }\end{array}$ & & & & & & \\
\hline & & $\begin{array}{lr}\text { Membuktikan } & \text { dua } \\
\text { segitiga } & \text { yang } \\
\text { konguren dan } & \text { dan } \\
\text { mencari panjang } \\
\text { salah satu sisinya }\end{array}$ & & & $\sqrt{ }$ & & 3 & \\
\hline & & $\begin{array}{l}\text { Membuktikan } \\
\text { kebenaran dari } \\
\text { bangun datar yang } \\
\text { kongruen dilihat dari } \\
\text { panjang sisi yang } \\
\text { diketahui. }\end{array}$ & & $\checkmark$ & & & 6 & 2 \\
\hline & $\begin{array}{l}\text { 2. Menentukan } \\
\text { bangun datar } \\
\text { yang sebangun }\end{array}$ & $\begin{array}{l}\text { Membuktikan dua } \\
\text { bangun datar dan dua } \\
\text { segitiga sebangun } \\
\text { atau tidak. }\end{array}$ & & & $\checkmark$ & & 4 & 1 \\
\hline & & $\begin{array}{l}\text { Membuktikan } \\
\text { kebenaran dua } \\
\text { bangun datar yang } \\
\text { dinyatakan sebangun } \\
\text { dengan } \\
\text { memperhatikan } \\
\text { perbandingan } \\
\text { panjang sisinya }\end{array}$ & & & & $\checkmark$ & 5 & 1 \\
\hline & & & 2 & 1 & 2 & 1 & & 6 \\
\hline
\end{tabular}

\section{Keterangan:}

1. Menginterpretasi permasalahan matematika.

2. Mengevaluasi kebenaran suatu argument.

3. Menganalisis permasalahan matematis.

4. Menarik analogi.

Yang dibutuhkan untuk mendapatkan nilai kemampuan berpikir reflektif matematis siswa adalah rubrik penilaian. Rubrik penilaian ini digunakan untuk mendapatkan hasil atau nilai dari jawaban untuk tiap butir soal yang telah dikerjakan siswa. Rubrik penilaian ini diambil dari Cai, Lane dan Jakabcsin sebagai berikut: (dalam Rafianti, 2017). Penelitian ini menggunakan data skor atau nilai Post Test dari kelas eksperimen dan kelas kontrol dengan materi yang digunakan yaitu kekongruenan dan kesebangunan. SoftwaremSPSS (Statistical Package for Social Sciences) versi 26 ini digunakan untuk analisis kuantitatif pada penelitian ini. Analisis data dalam penelitian ini menggunakan uji kesamaan dua rata-rata menggunakan analisis Independent Samples T Test. 
Pengaruh Self-Regulated Learning terhadap Kemampuan Berpikir Reflektif Matematis Siswa, Maura Noverienda Armelia, Ismail

\begin{tabular}{|l|c|}
\hline \multicolumn{1}{|c|}{ Reaksi terhadap soal } & Skor \\
\hline $\begin{array}{l}\text { Jawaban yang diberikan benar. Memberikan alasan jawaban } \\
\text { berdasarkan konsep matematika yang terlibat secara tepat dan } \\
\text { lengkap }\end{array}$ & 4 \\
\hline $\begin{array}{l}\text { Jawaban yang diberikan benar. Memberikan alasan jawaban } \\
\text { berdasarkan konsep matematika yang terlibat secara tepat namun } \\
\text { tidak lengkap. }\end{array}$ & 3 \\
\hline $\begin{array}{l}\text { Jawaban yang diberikan benar. Memberikan alasan jawaban } \\
\text { berdasarkan konsep matematika yangterlibat tetapi tidak tepat } \\
\text { dan tidak lengkap. }\end{array}$ & 2 \\
\hline $\begin{array}{l}\text { Jawaban yang diberikan salah atau tidak memberikan alasan } \\
\text { jawaban }\end{array}$ & 1 \\
\hline Tidak menjawab pertanyaan. & 0 \\
\hline
\end{tabular}

Gambar 1. Rubrik Penskoran

\section{Hasil dan Diskusi}

Dua kelas yang diambil dalam penelitian ini yaitu kelas IX-I yang jumlahnya 41 siswa dan IX-J yang berjumlah 42 siswa. Kelas IX-I menjadi kelas kontrol sedangkan IX-J menjadi kelas eksperimen. Pokok pembahasan yang diajarkan adalah materi kekongruenan dan kesebangunan. Penelitian ini dilakukan sebanyak tiga kali tatap muka. Pada pertemuan pertama dan kedua kelas eksperimen dilakukan pembelajaran yang menggunakan strategi Self-Regulated Learning, begitupun kelas kontrol pada pertemuan dan kedua dilakukan pembelajaran menggunakan strategi ekpositori. Pada pertemuan ketiga kedua kelas tersebut sama-sama dilakukan Post Test untuk mengukur kemampuan berpikir relfektif matematis siswa.

Berikut ini adalah hasil tes kelas eksperimen yang memakai strategi Self-Regulated Learning. Jumlah kelas eksperimen yaitu 42 siswa yang pengolahan datanya memerlukan perangkat lunak SPSS. Hasil data tersebut dapat dilihat pada tabel berikut:

Tabel 3. Hasil Post Test Kelas Eksperimen

\begin{tabular}{|r|r|r|r|r|r|}
\hline \multicolumn{2}{|c|}{} & Frequency & \multicolumn{1}{|c|}{ Percent } & Valid Percent & \multicolumn{2}{|c|}{$\begin{array}{c}\text { Cumulative } \\
\text { Percent }\end{array}$} \\
\hline \multirow{3}{*}{ Valid } & $65-70$ & 1 & 2,4 & 2,4 & 2,4 \\
\cline { 2 - 6 } & $71-76$ & 4 & 9,5 & 9,5 & 23,9 \\
\cline { 2 - 6 } & $77-82$ & 5 & 11,9 & 11,9 & 28,6 \\
\cline { 2 - 6 } & $83-88$ & 2 & 4,8 & 4,8 & 50,0 \\
\cline { 2 - 6 } & $89-93$ & 9 & 21,4 & 21,4 & 100,0 \\
\cline { 2 - 6 } & $94-98$ & 21 & 50,0 & 50,0 & \\
\cline { 2 - 6 } & Total & 42 & 100,0 & 100,0 & \\
\hline
\end{tabular}

Tabel 3 tersebut memperlihatkan hasil tes kelas eksperimen mengenai kemampuan berpikir reflektif yang nilainya di bawah rata-rata sebesar $28,6 \%$ dan persentasi nilai yang berada diatas rata-rata sebesar $71,4 \%$. Berikut ini adalah hasil tes yang dalam pembelajarannya menggunakan strategi ekspositori yaitu pada kelas kontrol dengan jumlah 41 siswa yang pengolahan datanya memerlukan software SPSS versi 26. Hasil tes tersebut dapat diamati pada tabel berikut: 
Tabel 4. Hasil Post Test Kelas Kontrol

\begin{tabular}{|l|l|r|r|r|r|}
\hline \multicolumn{2}{|c|}{} & Frequency & Percent & Valid Percent & Cumulative Percent \\
\hline Valid & $60-64$ & 1 & 2,4 & 2,4 & 2,4 \\
\cline { 2 - 6 } & $65-69$ & 3 & 7,3 & 7,3 & 9,8 \\
\cline { 2 - 6 } & $70-74$ & 6 & 14,6 & 14,6 & 24,4 \\
\cline { 2 - 6 } & $75-79$ & 17 & 41,5 & 41,5 & 65,9 \\
\cline { 2 - 6 } & $80-84$ & 9 & 22,0 & 22,0 & 87,8 \\
\cline { 2 - 6 } & $85-90$ & 5 & 12,2 & 12,2 & 100,0 \\
\cline { 2 - 6 } & Total & 41 & 100,0 & 100,0 & \\
\hline
\end{tabular}

Pada tabel tersebut dapat dilihat hasil tes siswa kelas kontrol mengenai kemampuan berpikir reflektif matematis yang memperoleh nilai di bawah rata-rata yaitu $24,4 \%$ dan persentasi nilai yang berada diatas rata-rata sebesar $75,6 \%$. Data yang telah dihitung menunjukkan adanya perbedaan antara hasil tes kemampuan berpikir reflektif yang telah dilakukan kelas eksperimen dan kontrol. Pengelolahan datanya membutuhkan perangkat lunak SPSS. Dibawah ini merupakan tabel hasil perhitungannya:

Tabel 5. Perbandingan Hasil Tes Kelas Eksperimen dan Kelas Kontrol

\begin{tabular}{|l|r|r|}
\hline & Eksperimen & \multicolumn{1}{|c|}{ Kontrol } \\
\hline N & 42 & 41 \\
\hline Mean & 89 & 76,17 \\
\hline Median & 93 & 75 \\
\hline Std. Deviation & 8,69 & 6,629 \\
\hline Variance & 75,512 & 43,945 \\
\hline Minimum & 65 & 60 \\
\hline Maximum & 98 & 90 \\
\hline
\end{tabular}

Pada Tabel 5 memperlihatkan perbandingan hasil tes kedua kelas yang memiliki perbedaan pada perhitungan nilai rata-rata. Dimana kelas eksperimen mean nya adalah 89,00 dan kelas kontrol mean nya adalah 76,17 . Nilai maksimumnya adalah 98 dari kelas eksperimen dan nilai minimumnya adalah 60 dari kelas kontrol. Pada tabel 5 menunjukkan perbedaan varians dan standart deviasi dari dua kelas yang terlibat. Kelas eksperimen nilai varians adalah 75,512 dan kelas kontrol menunjukkan hasil data 43,945. Dari hasil varians kedua kelas tersebut menunjukkan varian dari kelas kontrol lebih rendah dibandingkan dengan kelas eksperimen. Jadi hal tersebut menunjukkan kelas eksperimen mempunyai persebaran nilai yang lebih bervariasi dibanding kelas kontrol yang cenderung kurang bervariasi.

Perbedaan hasil data selanjutnya yaitu pada nilai standar deviasi. Pada tabel tersebut ditunjukkan bahwa standar deviasi kelas eksperimen menunjukkan hasil data sebesar 8,69 dan hasil data kelas kontrol yaitu 6,629. Perbedaan tersebut menunjukkan bahwa standar deviasi dari kelas eksperimen lebih tinggi dibandingkan kelas kontrol yang artinya nilai rata-rata kelas eksperimen mempunyai nilai yang berjauhan sedangkan kelas kontrol nilai rata-ratanya cenderung berdekatan.

Dari segi indikatornya juga dapat dilihat perbandingan antara kemampuan kelas eksperimen dan kelas kontrol. Kemampuan berpikir reflektif mempunyai empat indikator yaitu : menganalisis, menarik 
Pengaruh Self-Regulated Learning terhadap Kemampuan Berpikir Reflektif Matematis Siswa, Maura Noverienda Armelia, Ismail

analogi, menginterpretasi dan mengevaluasi. Dibawah ini dapat dilihat hasil tes kemampuan berpikir reflektif berdasarkan indikatornya:

Tabel 6. Perbandingan Rata-rata Kemampuan Berpikir Reflektif Matematis Siswa Kelas Eksperimen dan Kelas Kontrol Berdasarkan Indikatornya

\begin{tabular}{|c|c|c|c|c|}
\hline \multirow{2}{*}{ No } & \multirow{2}{*}{ Indikatori } & \multirow{2}{*}{ skor ideal } & eksperimen & Kontrol \\
\cline { 3 - 5 } & & $\begin{array}{c}\text { Nilai rata- } \\
\text { rata }\end{array}$ & $\begin{array}{c}\text { Nilai Rata- } \\
\text { rata }\end{array}$ \\
\hline 1 & Menginterpretasi & 8 & 95 & 82 \\
\hline 2 & Mengevaluasi & 4 & 90 & 80 \\
\hline 3 & Menganalisis & 8 & 85 & 76 \\
\hline 4 & Menarik Analogi & 4 & 87 & 78 \\
\hline
\end{tabular}

Hasil rata-rata kelas eksperimen dan kontrol berdasarkan indikator disajikan pada tabel empat diatas. Apabila ditinjau dari indikator kemampuan berpikir reflektif rata-rata hasil jawaban siswa eksperimen mampu memberikan jawaban dengan benar disertai penjabaran dan penjelasan mengenai soal yang diberikan dengan cara yang jelas. Sedangkan siswa kelas kontrol juga mampu menjawab pertanyaan dengan benar, tetapi siswa kelas kontrol menjawab lebih singkat tanpa menjabarkan atau menjelaskan jawabannya dengan runtut. Keadaan terjadi karena strategi Self-Regulated Learning terdiri dari langkah-langkah pembelajaran yang bisa menaikkan kemampuan berpikir reflektif siswa.

Hal tersebut menandakan bahwa perbedaan perilaku yang dilakukan tersebut dapat mempengaruhi kemampuan berpikir reflektif matematis. Secara keseluruhan skor rata-rata yang dimiliki kelas eksperimen lebih unggul dari pada kelas kontrol. Dari indikator menarik analogi, mengevaluasi, menganlisis, dan menginterpretasi. Nilai tertinggi adalah pada indikator menginterpretasi di kelas eksperimen dan nilai terendah dari keempat indikator tersebut adalah indikator menganalisis.

Untuk dapat menyimpulkan hipotesis yang telah dibuat, dilakukan pengujian prasyarat analisis yaitu meliputi uji homogenitas, uji hipotesis, dan uji normalitas. serta yang digunakan untu pengujian ini adalah perangkat lunak SPSS versi 26. Uji normalitas ini digunakan guna mengetahui data yang digunakan apakah berasal dari populasi berdistribusi normal atau tidak. Hasil perhitungan uji normalitas dapat dilihat pada Tabel 7.

Tabel 7. Hasil Uji Normalitas Tes Kemampuan Berpikir Reflektif Matematis

Tests of Normality

\begin{tabular}{|c|c|c|c|c|c|c|c|}
\hline & \multirow[b]{2}{*}{ Jenis Kelas } & \multicolumn{3}{|c|}{ Kolmogorov-Smirnov ${ }^{a}$} & \multicolumn{3}{|c|}{ Shapiro-Wilk } \\
\hline & & Statistic & Df & Sig. & Statistic & Df & Sig. \\
\hline Hasil & eksperimen & .102 & 42 & $\angle U$ & .947 & 42 & \\
\hline & Control & .111 & 41 & $.200^{*}$ & .959 & 41 & .145 \\
\hline
\end{tabular}


Tabel 8. Hasil Uji Homogenitas Tes Kemampuan Berpikir Reflektif Matematis Siswa Kelas Eksperimen dan Kelas Kontrol

Test ofiHomogeneity of Variance

\begin{tabular}{|l|r|r|r|r|}
\hline & Levene Statistic & df1 & df2 & Sig. \\
\hline Hasil Based on Mean & .040 & 1 & 81 & .842 \\
Based on Median & .066 & 1 & 81 & .798 \\
Based on Median and with adjusted df & .066 & 1 & 80.981 & .798 \\
Based on trimmed mean & .041 & 1 & 81 & .841 \\
\hline
\end{tabular}

Pada tabel 8 menjelaskan bahwa berdasarkan hasil uji homogenitas memiliki varians homogen dengan uji yang digunakan yaitu uji Levene. taraf signifikansinya adalah $\alpha=0,05$ karena nilai sig dari data penelitian ini sebesar 0,842. Nilai sig 0,842 lebih besar dibanding $\alpha=0,050$, oleh karena itu data hasil tes kemampuan berpikir reflektif dari dua kelas tersebut mempunyai varians yang homogen. Pengujian yang sudah dilakukan menunjukkan hasil data tes memiliki varians yang homogen dan berdistribusi normal. Maka untuk mengetahui kemampuan berpikir reflektif matematis kelas eksperimen lebih unggul dibandingkan kelas kontrol perlu melaksanakan pengujian perbedaan dua rata-rata. Cara yang dapat digunakan adalah uji hipotesis yaitu analisis independent sample T test. Hasil perhitungan uji hipotesis dapat dilihat pada tabel dibawah ini.

Tabel 9. Hasil Uji Hipotesis Tes Kemampuan Berpikir Reflektif Matematis Siswa Independent Samples Test

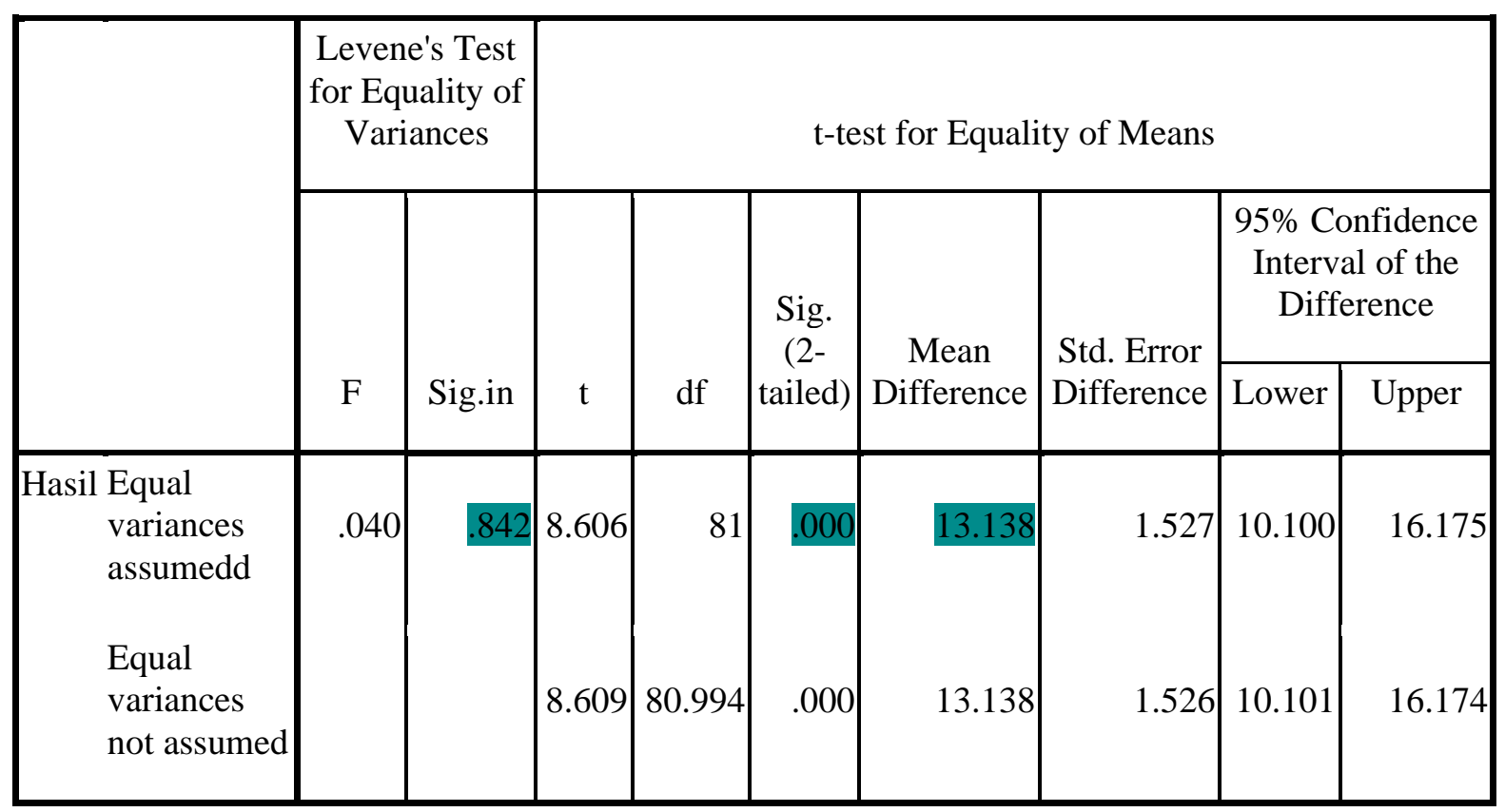

Kemampuan berpikir reflektif dengan thitung data Equal variances assumsed adalah 8,606 dan nilai Sig.(2-tailed) adalah 0,000. Kemudian untuk mencari uji satu arah adalah dengan membagi dua nilai Sig.(2- 
Pengaruh Self-Regulated Learning terhadap Kemampuan Berpikir Reflektif Matematis Siswa, Maura Noverienda Armelia, Ismail

tailed) yang hasilnya adalah 0,000. Dengan uji t dengan taraf $\alpha=0,05$ menandakan nilai $\operatorname{Sig}$ (1-tailed) lebih rendah dari nilai signifikansi $\alpha$. Oleh karena itu kemampuan berpikir reflektif siswa dari kelas eksperimen lebih unggul atau lebih tinggi apabila dibandingkan dengan kelas kontrol.

\section{KESIMPULAN}

Berdasarkan pembahasan tersebut dapat disimpulkan Strategi Self-Regulated Learning digunakan dalam pembelajaran kelas eksperimen yang memiliki kapasitas penalaran kecerdasan yang lebih unggul atau lebih baik. Pada indikator menginterpretasi lebih unggul apabila dibandingkan dengan ketiga indikator lainnya. Siswa yang pembelajarannya menggunakan strategi Self-Regulated Learning mampu mengendalikan kemampuan berpikirnya untuk memecahkan permasalahan matematik. Strategi ekspositori digunakan dalam pembelajaran kelas kontrol yang masih tergolong rendah. Indikator menginterpretasi pada strategi ekspositori mempunyai hasil yang lebih baik apabila dibandingkan dengan ketiga indikatornya. Strategi ekspositori yang digunakan dalam pembelajaran ini kurang bisa merefleksikan kemampuan berpikirnya dalam menyelesaikan atau memecahkan masalah matematika. Dari uji hipotesis yang memperlihatkan $\mathrm{p}$-value $\leq \alpha(0,05)$ yang artinya kemampuan berpikir reflektif matematis siswa yang pembelajarannya menggunakan strategi Self-Regulated Learning lebih tinggi dibandingkan dengan kelas kontrol yang menggunakan strategi ekspositori.

\section{REFERENSI}

Anwar, S. (2018). Teoritik Tentang Berpikir Reflektif siswa Dalam Pengajuan Masalah Matematis. Jurnal Numeracy, 5(1), 91-101.

Dewey, J. (1933). how we think. Boston : D.C. Heath \& Co.

Fahiroh, Y. U. (2020). Pengaruh Model Pembelajaran The Learning Cell dengan Strategi Self-Regulated Learning Terhadap Kemampuan Komunikasi dan Berpikir Reflektif Matematis Siswa. http://digilib.uinsby.ac.id/id/eprint/41985

Fuady, A. (2006). Berfikir reflektif dalam pembelajaran matematika. Jurnal Ilmiah Pendidikan Matematika, $1(2)$.

Hamonangan, R. H., \& Widyarto, S. (2019). Pengaruh Self-Regulated Learning dan Self Control Terhadap Hasil Belajar Bahasa Indonesia. JDPP, 7(1).

Hidayat, W., \& Sumarmo, U. (2013). Kemampuan Komunikasi dan Berpikir Logis Matematik serta Kemandirian Belajar. Delta-Pi: Jurnal Matematika Dan Pendidikan Matematika, 2(1), 1-14.

Hidayati, I. S., Program, P., Pendidikan, S., Sarjanawiyata, U., \& Yogyakarta, T. (2016). Meningkatkan minat dan prestasi belajar tentang fpb dan kpk melalui strategi pembelajaran ekspositori 1), 2). Jurnal Pendidikan Matematika, 4(1), 165-170.

Kusumaningrum, M., \& Saefudin, A. A. (2012). Mengoptimalkan Kemampuan Berpikir Matematika melalui Pemecahan Masalah Matematika. Prosiding Kontribusi Pendidikan Matematika Dan 
Matematika Dalam Membangun Karakter Guru Dan Siswa, 978-979.

Latipah, E. (2015). Strategi Self-Regulated Learning dan Prestasi Belajar: Kajian Meta Analisis. Jurnal Psikologi, 37(1), 110 - 129-129. https://doi.org/10.22146/jpsi.7696

Masamah, U. (2017). Retensi kemampuan berpikir reflektif melalui pembelajaran berbasis masalah ditinjau dari kemampuan awal matematika siswa man ngawi. Journal Of Mathematic Teaching, 1(17).

Mukhid, A. (1998). STRATEGI SELF-REGULATED LEARNING (Perspektif Teoritik). Journal of Educational Psychology, 82(1), 33-40.

Nikmah, S. J. (2018). Pengaruh Model Pembelajaran Concrete-Pictorial_Abstract (C-P-A) Dengan Strategi Klasifikasi Pengetahuan Terhadap Kemampuan Berpikir Reflektif Matematis. Universitas Islam Negeri Syarif Hidayatullah.

Nindiasari, H., Kusumah, Y., Sumarmo, U., \& Sabandar, J. (2014). Pendekatan Metakognitif Untuk Meningkatkan Kemampuan Berpikir Reflektif Matematis Siswa SMA. Jurnal Ilmu Pendidikan Dan Pengajaran, 1(1).

Sabandar, J. (2009). Berpikir Reflektif dalam Pembelajaran Matematika. UPI: Himpunan Matematika Indonesia, 1, Tersedia, http://fmipa.um.ac.id, [15 Maret 2017]. http://file.upi.edu/Direktori/FPMIPA/JUR._PEND._MATEMATIKA/194705241981031JOZUA_SABANDAR/KUMPULAN_MAKALAH_DAN_JURNAL/Berpikir_Reflektif2.pdf

Sagala, H. S. (2010). Konsep dan Makna Pembelajaran. Bandung : Alfabeta.

Sudarma, M. (2016). Mengembangkan Keterampilan Berpikir Kreatif(1st ed.). Jakarta : Rajawali Pers.

Sugiyono. (2012). Metode Penelitian Pendidikan Pendekatan Kuantitatif, Kualitatif, dan R\&D. Bandung: Alfabeta.

Sukmadinata, \& Nana, S. (2008). Metode Penelitian Pendidikan (4th ed.). Bandung: PT.Remaja Rosdakarya.

Suyadi. (2013). Strategi Pembelajaran Pendidikan Karakter (1st ed.). Bandung : PT : Remaja Rosdakarya. 